Economic Features of formation and implementation of

State Migration

Policy in Russia 


\title{
Economic Features of formation and implementation of State Migration Policy in Russia
}

\section{Características económicas de la formación e implementación de la Política de Migración Estatal en Rusia}

\begin{abstract}
Authors
Angela Sergeevna Igonina. Kazan Federal University, Institute of Management, Economics and Finance.

E-mail:Angml@yandex.ru

Denis Ivanovich Igonin. Kazan Federal University, Institute of social and philosophical studies and mass media

Ruslan Faritovich Garipov'Kazan Federal University, Institute of social and philosophical studies and mass media

Fecha de recibido: 13 de noviembre de 2019

Fecha de aceptado para publicación: 30 de noviembre de 2019

Fecha de publicación: 10 de diciembre de 2019

Abstract

The effectiveness of the socio-economic system development of any modern state directly depends on the rational formation and effective implementation of the state migration policy. The purpose of the paper is to analyse the trends and problems of migration relations development in the Russian Federation, the specifics of the state migration policy and to develop recommendations for its improvement. The paper analyses the main elements of the regulatory framework regarding the regulation of the state migration policy in the Russian economy. The main approaches to the rational implementation of the state migration policy in relation to illegal migrants are highlighted. The dynamics of influence of migration inflows into the Russian Federation in 2010 - 2018 to crime rate is statistically evaluated. It is shown that from the point of view of maximizing the average level of profitability of products in the Russian economy, the annual flow of migrants of working age should be about 200-250 thousand people. Recommendations have been developed to improve the state migration policy in Russia.
\end{abstract}

Keywords:economy, migration, migration process, state migration policy.

La efectividad del desarrollo del sistema socioeconómico de cualquier estado moderno depende directamente de la formación racional y la implementación efectiva de la política de migración estatal. El propósito del documento es analizar las tendencias y los problemas del desarrollo de las relaciones migratorias en la Federación de Rusia, los detalles de la política de migración estatal y desarrollar recomendaciones para su mejora. El documento analiza los principales elementos del marco regulatorio con respecto a la regulación de la política de migración estatal en la economía rusa. Se destacan los principales enfoques para la implementación racional de la política de migración estatal en relación con los inmigrantes ilegales. La dinámica de la influencia de los flujos migratorios en la Federación de Rusia en 2010-2018 a la tasa de criminalidad se evalúa estadísticamente. Se muestra que desde el punto de vista de maximizar el nivel promedio de rentabilidad de los productos en la economía rusa, el flujo anual de migrantes en edad de trabajar debería ser de aproximadamente 200-250 mil personas. Se han desarrollado recomendaciones para mejorar la política de migración estatal en Rusia.

Palabras clave: economía, migración, proceso migratorio, política de migración estatal. 


\section{Introduction}

Regulation of migration is one of the basic directions of state socio-economic policy. Lack of attention to the migration development problems in a state, as a rule, provokes an increase in domestic crime, other forms of social deviations, and a decrease in the level of social well-being in general.

The purpose of the paper is to analyse the trends and problems of the migration relations development in the Russian Federation, the characteristics of the state migration policy and to develop recommendations for its improvement. The objectives of the study are:

- Analysis of the regulatory framework of the state migration policy in the Russian Federation and the main approaches to its implementation;

- Carrying out of an economic and statistical study of the migration flow impact on crime rate and the average profitability of products in the Russian economy in 2010 - 2018;

- Development of recommendations for improving the state migration policy in the Russian Federation.

\section{Materials And Methods}

The main research methods are the analysis of the regulatory framework in the field of migration policy in the Russian Federation, a comparative description of the main approaches to the organization of migration policy presented in the specialized literature, the study of the migration flow dynamics, one-way correlation and regression analysis.

\section{Results And Discussion}

It should be noted that there is no consensus on the main issues of the state migration policy implementation in the specialized literature, especially regarding the regulation of the illegal migration processes. For example, D. Martin argues the need for an extremely tough solution to this problem, the unconditional expulsion of all groups of illegal migrants and even their criminal prosecution (Martin, 2013). K. Arar and J. Brooks, on the contrary, advocate the consistent integration of illegal migrants into the national socio-economic system, giving them legal status, training migrants, etc (Arar \& Brooks, 2019).

The normative basis for the implementation of the state migration policy in the Russian Federation in relation to foreign citizens is the Federal Law "On the Migration Registration of Foreign Citizens and Stateless Persons in the Russian Federation" (Federal Law, 2019). The specified legal act regulates, in particular, the procedure for migration registration of foreign citizens, the rights and obligations of the latter in the implementation of civil legal relations of a migration nature, the composition and structure of domestic bodies of migration control and accounting, etc. Substantive adjustments are made regularly to the indicated document.

However, as noted, in particular, by A.V. Yakimov, the law enforcement practice on implementing this basic law in the formation and implementation of the state migration policy of the Russian Federation is far from perfect: in particular, the current legislation does not exclude significant corruption risks in the studied area (Yakimov, 2019). The 
rather high risks of corruption in the development of migration policy in Russia are also indicated by V.M. Kapitsyn (Kapitsyn, 2019).

According to T.N. Balashova, one of the key problems of regulating migration in the Russian Federation is a significant gap between the current legislative framework and the trends in economic practice in this area (Grebenyuk \& Krasnikova, 2017). Indeed, for example, the current strategic demographic policy concept in the Russian Federation until 2025 was adopted in 2007, and the latest adjustments to its content were made only in 2014 (The concept of demographic policy in the Russian Federation for the period until 2025, 2014). In addition, the provisions of this normative act are, in our opinion, quite declarative in their nature.

Data on the dynamics of legal migration flow to the Russian economy are presented in Table 1

Table 1. Comparative dynamics of legal migration in the Russian Federation and a number of socio-economic indicators

\begin{tabular}{|l|l|l|l|l|}
\hline Years & $\begin{array}{l}\text { The total number of legal } \\
\text { migrants in the Russian } \\
\text { Federation, thousand } \\
\text { people }\end{array}$ & $\begin{array}{l}\text { The number of migrants of } \\
\text { working age, thousand } \\
\text { people }\end{array}$ & $\begin{array}{l}\text { The number of registered } \\
\text { crimes in the Russian } \\
\text { Federation, a thousand } \\
\text { units }\end{array}$ & $\begin{array}{l}\text { Average profitability of } \\
\text { products in the Russian } \\
\text { economy, } \%\end{array}$ \\
\hline 2010 & 191 & 134 & 2628 & 8.4 \\
\hline 2011 & 239 & 167 & 2632 & 9.9 \\
\hline 2012 & 311 & 218 & 2561 & 11.7 \\
\hline 2013 & 452 & 316 & 2578 & 8.3 \\
\hline 2014 & 507 & 355 & 2411 & 8.1 \\
\hline 2015 & 598 & 419 & 2388 & 8.7 \\
\hline 2016 & 575 & 403 & 2160 & 9.4 \\
\hline 2017 & 571 & 400 & 2058 & 9.2 \\
\hline 2018 & 556 & 389 & 2021 & 8.9 \\
\hline
\end{tabular}

As shown in Table 1, in 2010 - 2015 the total number of legal migrants to the economy of the Russian Federation has grown quite significantly, by 3.02 times. At the same time, in 2015 - 2018 the number of this category of Russian residents decreased by $7.1 \%$, which was primarily due to the tightening of the procedure for obtaining migration status and the outflow of part of migrants to the countries of arrival.

Quite widespread is the point of view that increasing the intensity of migration provokes an increase in domestic crime. To assess the correctness of this thesis, we will conduct an economic and statistical assessment of the impact of the number of migrants into the Russian Federation on the crime rate (Fig. 1). 


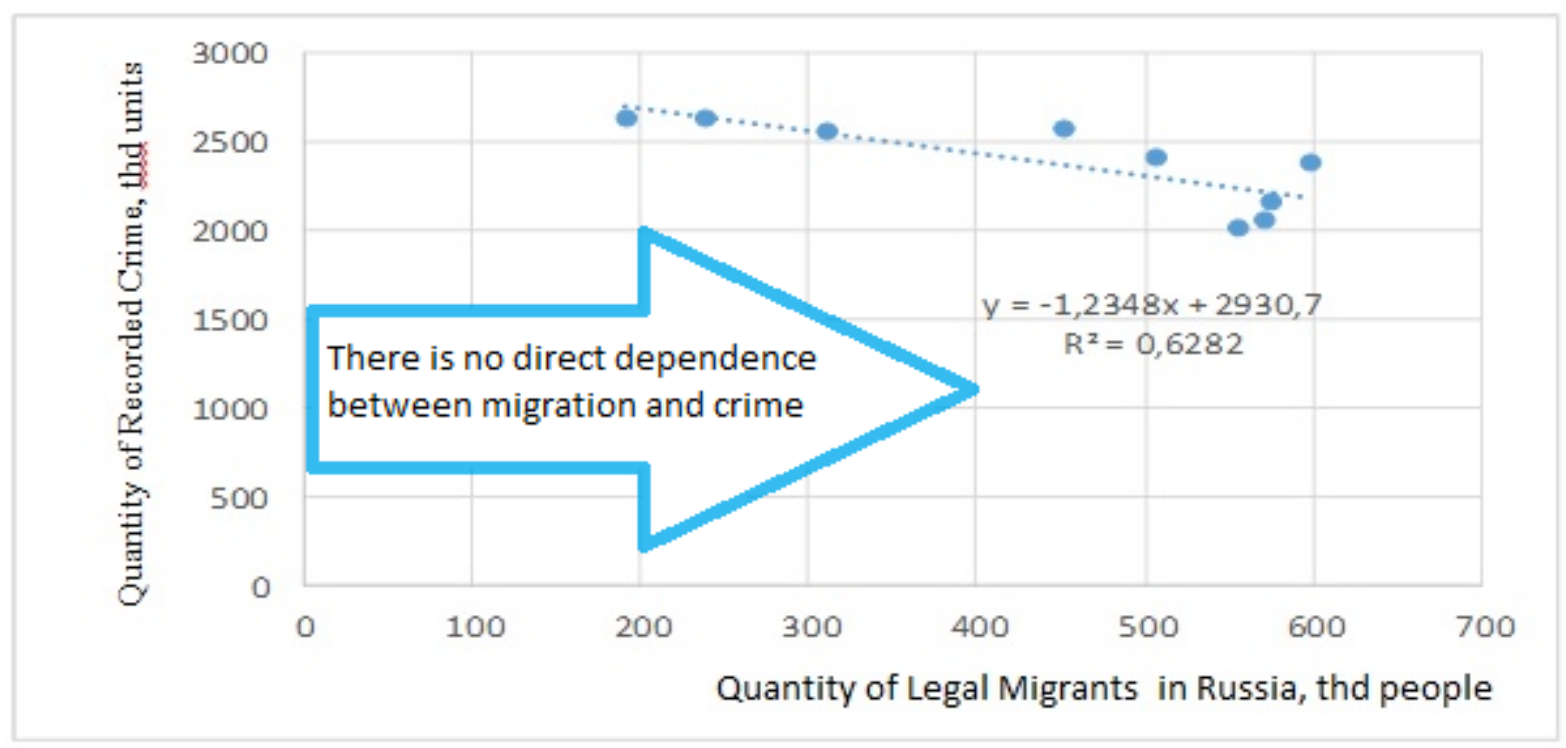

Fig. 1. The economic and statistical function of the effect of the legal migration level of the registered crime dynamics in the Russian Federation (2010 - 2018) (based on own research)

As shown in fig. 1, a direct statistical relationship between the level of migration and the dynamics of crime in Russia in 2010 - 2018 was absent. Accordingly, unlike the widespread opinion, a legal migration flow is not a significant factor in the intensification of the crime rate in the national socio-economic system.

At the same time, an increase in the number of migrants of working age, ideally, should positively affect the efficiency of the financial and economic development of the economy, for example, in terms of the average profitability of products. This kind of influence should take place through the use of relatively cheap, but also relatively skilled labour of migrants.

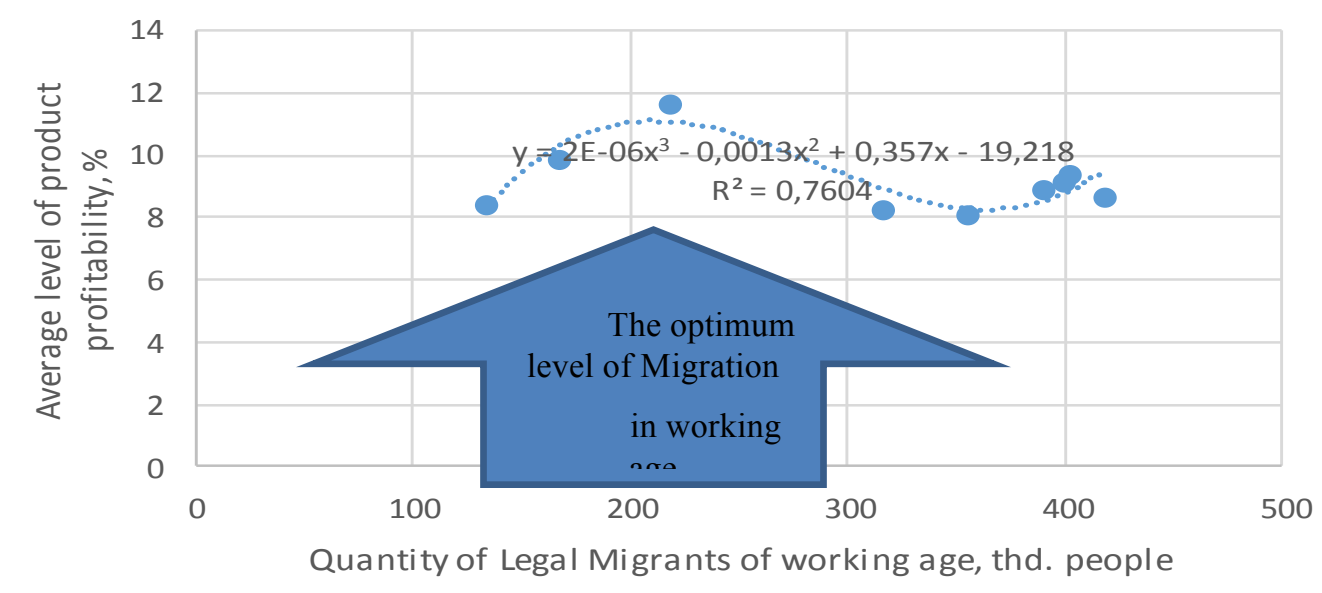

Fig. 2. The economic and statistical function of the effect of the legal working-age migration level on the dynamics of the average profitability of products in the economy of the Russian Federation (2010 - 2018) (based on our own research) 
As shown in fig. 2, the relationship between the number of legal migrants of working age and the average profitability of products in the Russian economy is approximated by a polynomial function, the local extremum of which is at the level of about 220 thousand people. Accordingly, the optimal range of qualified legal migrants in the Russian economy may vary at the level of $200-250$ thousand people.

A more significant number of migrants of working age can negatively affect the development of the national labour market in terms of discriminating labour rights of Russian Federation citizens with a similar level of qualification. As for the statistical analysis of illegal migration, it is difficult in modern conditions due to the absence of any representative estimate of the size of this population group and their demographic and vocational qualification structure.

We have formed Recommendations for improving the main directions of state migration policy in the Russian Federation, which should be differentiated by the main types of population migration (Table 2).

Table 2. Recommendations for improving the main directions of state migration policy in the

\section{Russian Federation}

\begin{tabular}{|c|c|}
\hline The main types of migration & $\begin{array}{l}\text { The main proposed development and improvement areas in the system of state migration } \\
\text { regulation }\end{array}$ \\
\hline 1. External migration & $\begin{array}{l}\text { - tightening the financial responsibility of employers for the use of illegal migrants' labour; } \\
\text { - stimulation of highly qualified personnel attraction from neighbouring countries; } \\
\text { - creating conditions for the prompt and effective socialization of legal migrants. }\end{array}$ \\
\hline $\begin{array}{l}2 . \quad \text { Intraregional } \\
\text { interregional migration }\end{array}$ & $\begin{array}{l}\text { - Assistance in increasing the efficiency and safety of the so-called push-pull migration } \\
\text { (permanent migration of residents to work from one city or region to another and returning back at } \\
\text { night or on weekends); } \\
\text { - Formation of a management strategy for inter-regional migration flows; } \\
\text { - Creating conditions for interregional migration of skilled labour to the most economically } \\
\text { depressed regions of the Russian Federation. }\end{array}$ \\
\hline 3. Emigration & $\begin{array}{l}\text { - The creation of conditions for the retention of the most qualified graduates from institutions in } \\
\text { the Russian Federation in the domestic economy; } \\
\text { - The development of preferential mortgage programs for young people as a factor in } \\
\text { counteracting the emigration of the most qualified personnel [4, p. 67]. }\end{array}$ \\
\hline
\end{tabular}

\section{Summary}

In accordance with the proposed approach, in order to improve the processes of formation and implementation of the state migration policy in the Russian Federation, it is proposed to combine sanctions (toughening fines for employers using informal labour of illegal migrants) with measures to stimulate the economic integration of legal migrants and their families into social relationship structure. So, at present, many migrants to Russia and their family members do not have access to full-fledged education and health care due to restrictions related to the speed of obtaining passports, other official documents, as well as compulsory health insurance policies. 
In our opinion, it is necessary to strengthen additionally the incentives that prevent the emigration of the most qualified personnel with higher education, primarily graduates of Russian natural and technical universities, to foreign corporations and research centres. The key role in solving this problem should be played by preferential federal and regional mortgage programs for qualified young professionals.

A separate problem is the regulation of the internal, primarily the so-called push-pull migration of labour resources. In our opinion, it is necessary to ensure the dynamics of this kind of migration flows in accordance with the strategic needs of individual regions of the Russian Federation in personnel of the corresponding profile. In addition, the state should ensure an increase in the security level of the processes of push-pull labour migration. In general, it is advisable to form a special federal target program (FTP) in this area (Oveisi et al., 2018b; Sohrabi, 2017; Pontes \& Albuquerque, 2017).

Thus, unlike, for example, the studies of D. Martin, we did not reveal the existence of a direct close relationship between the dynamics of migration and the crime rate in the Russian economy. This indicates a certain exaggeration of the social danger of the migration flow, which is presented both in the specialized literature and is quite common in the framework of everyday consciousness (Martin, 2013; Oveisi et al., 2018a; Agara, 2017).

\section{Conclusion}

In general, the main directions for improving state migration policy in the Russian economy should be:

- Improving the statistical accounting of migration, especially its illegal segment, using the economic and statistical analysis tools when justifying the directions for improving the migration policy, by analogy with the one given in this paper;

- Formation of a viable strategy for state management of migration processes that meet such basic principles as consistency, objectivity, transparency, comprehensive minimization of the level of corruption risks in the process of regulating migration;

- Improving the mechanisms for the integration of legal migrants into society, into national systems of education, healthcare and culture;

- Emphasis on the management of processes of intra-regional and inter-regional, including push-pull migration of labour resources, which is currently not given much attention in the Russian Federation;

- Development of international cooperation systems in the implementation of the main directions of state migration policy, primarily through the EAEU and BRICS.

\section{Acknowledgement}

The work is performed according to the Russian Government Program of Competitive Growth of Kazan Federal University.

\section{References}

Agara, T. (2017). The Role of Woman in Terrorism and Investigation of Gendering Terrorism. Journal of Humanities Insights, 01(02), 46-56. 
Arar, K., \& Brooks, J. (2019). Education, immigration and migration. Wash.: Emerald Group Pub Ltd, 328 p.

Federal Law, (2019). On Migration Registration of Foreign Citizens and Stateless Persons in the Russian Federation. dated July 18, 2006 No. 109-FZ (as amended and supplemented on March 14, 2019) [Economic and Legal Base "Guarantor"]. Access mode: free (access date 2.08.2019).

Grebenyuk, A. A., \& Krasnikova, E. S. (2017). Socio-economic factors of the "brain drain" from Russia. Migration policy, 1, 65-78.

Kapitsyn, V. M. (2019). Migration policy. The experience of Russia and foreign countries. M.: Infra-M, 480 p.

Martin, D. (2013). Forced migration and law policy. NY.: West Academic Publishing, 605 p.

Oveisi, K., Esmaeilimotlagh, M., Alizadeh, F., \& Asadollahi Kheirabadi, M. (2018a). An Investigation on Coping Skills Training Effects on Mental Health Status of University Students. Journal of Humanities Insights, 02(01), 37-42.

Oveisi, K., Esmaeilimotlagh, M., Alizadeh, F., \& Asadollahi Kheirabadi, M. (2018b). To Study the Prevalence of Post-Traumatic Stress Disorder and its Comorbidity with personality disorders among veterans of Tehran. Journal of Humanities , 02(01), 0613.

Pontes, L. B., \& Albuquerque, A. B. (2017). Managing Database Services: An Approach Based in Information Technology Services Availabilty and Continuity Management. Journal of Information Systems Engineering \& Management, 2(1), 1. https://doi.org/10.20897/jisem.201701

Sohrabi, M. (2017). The Relationship between Non-Financial Innovative Management Accounting Tools and Risk and Return of Iranian Stock Market Listed Companies. Dutch Journal of Finance and Management, 1(2), 40. https://doi.org/10.29333/djfm/5816

The concept of demographic policy in the Russian Federation for the period until 2025, (2014). Approved by Decree of the President of the Russian Federation dd. October 9, 2007 No. 1351 (as amended and supplemented on July 1, 2014) [Economic and Legal Base "Guarantor"]. Access mode: free (access date 2.08.2019).

Yakimov, A. V. (2019). Modern problems of the migration policy development of in the Russian Federation. Bulletin of Economics and Management, 4, 71 - 74. 